\title{
Africa and MENA Regions (2019)
}

\author{
Nicholas Wasonga Orago*
}

\section{Introduction}

Africa and MENA regions continue to experience extreme weather events resulting from climate change. Regional institutions and countries have developed legal, policy and institutional frameworks to deal with these challenges as discussed in Volume 1 of this Yearbook. ${ }^{1}$ In this 2 nd Volume, we look at the progressive development of these legal frameworks in 2019 and how they have been used to respond to natural disasters in 2019.

The IPPC is warning that Africa is warming at a faster pace $-1.5^{-2}{ }^{\circ} \mathrm{C}$ above the global average, ${ }^{2}$ with adverse consequences to people, ecosystems and livelihoods experienced in Africa in 2019. The Horn of Africa has experienced erratic climatic conditions of crippling drought (below 50\% of the annual average rainfall in long rains seasons of March-May 2019) followed by heavier than normal rainfalls in short spans of time (rains of 3 -times above the normal annual average in months of October and November 2019) that have led to devastating flash floods and landslides resulting in loss of lives, livelihoods and displacement of people. ${ }^{3}$ The flooding resulted in displacement of 200.000 people in Ethiopia, 160.000 in Kenya, 370.00o in Somalia, affecting a total of 3.4 million

* Llb (Nairobi) LlM (Pretoria) Lld (Western Cape); Senior Lecturer, University of Nairobi School of Law.

1 Nicholas Orago, 'Africa and MENA Regions (2018)', (2019) 1 Yearbook of International Disaster Law, 326-335, available at <https://brill.com/view/journals/yido/1/1/article-p326_326.xml> last accessed (as any subsequent URL) on 20 May 2020.

2 Francois Engelbrecht, 'Projections of future climate change in Africa - the physical science base' (June 2019) 10 <https://apps.ipcc.ch/outreach/aboutevent.php?q=458>; Kendon et al, 'Enhanced future changes in wet and dry extremes over Africa at convection-permitting scale', Nature Communications (2019) 2ff.

3 Есно, 'Horn of Africa: Floods in Ethiopia, Kenya and Somalia' (26 October 2019) <https:// reliefweb.int/report/ethiopia/horn-africa-floods-ethiopia-kenya-and-somalia-un-ocha -national-authorities-fao-red>. 
people in the region. ${ }^{4}$ Cyclone Pawan worsened the flooding in Somalia, displacing a further 55.000 people. ${ }^{5}$ South Sudan equally experienced flooding that affected over 1 million people, displaced 180.000 and damaged 74.000 hectares of cultivated land. ${ }^{6}$ 2019's wet weather in the Horn created conducive ecological conditions for the invasion of the worst plague of desert locusts in a generation that have devoured hundreds of kilometres of food and pasture, further exposing the region to potential food insecurity in 2020.7

In the Sahel region rising temperatures has resulted in longer periods of droughts alternating with shorter periods of erratic and intense rainfall leading to floods that have degraded $80 \%$ of farmland and pastures undermining food security and rendering 15.5 million people extremely food insecure. ${ }^{8}$ The situation has been exacerbated by the shrinking of Lake Chad due to climate change, with the lake only one-tenth of what it used to be, denying people opportunity for fishing and irrigation to boost food security. ${ }^{9}$

Southern Africa was 2019's disaster epicentre, suffering from long and severe drought that heavily affected food security in many of its countries. In Madagascar, the drought affected more than 2.6 million people, with 916.ooo in need of immediate food aid. ${ }^{10}$ Zambia recorded the lowest levels of precipitation since 1981, resulting in over 2.3 million people in urgent need of food aid. ${ }^{11}$ Mozambique bore the brunt, with two deadly cyclones in a single season - Idai and Kenneth making landfall with devastating effect. Cyclone Idai resulted in over 650 fatalities, injured over 1.6oo people and exposed more to cholera (6.627) and malaria (14.863), destroyed 240.00o homes, displaced

UN-OCHA, 'East Africa Region: Regional Floods and Locust Outbreak Snapshot January 2020' (17 January 2020) <https://reliefweb.int/report/south-sudan/eastern -africa-region-regional-floods-and-locust-outbreak-snapshot-january-2020>.

ICRC, 'Caught between extremes: violence, drought, flooding and now a locust invasion' (2 February 2020) <https://reliefweb.int/report/ethiopia/caught-between -extremes-violence-drought-flooding-and-now-locust-invasion $>$.

UN-OCHA, 'South Sudan floods - June 2019' <https://reliefweb.int/disaster/fl-2019 -oooo62-ssd>.

$7 \quad$ Ibid; Save the Children 'Plague of locusts ravages three East African countries as region prepares for another year of hunger' (23 January 2020) <https://reliefweb.int/report/somalia/ plague-locusts-ravages-three-east-african-countries-region-prepares-another-year>.

8 Christian Bodewig, 'Climate change in the Sahel: How can cash transfers help protect the poor' (4 December 2019) <https://www.brookings.edu/blog/future-development/2019/ 12/o4/climate-change-in-the-sahel-how-can-cash-transfers-help-protect-the-poor/>. CARE International, 'Suffering in silence: The 10 most underreported crises of 2019' (2019) 15, $<$ https://insights.careinternational.org.uk/media/k2/attachments/CARE_Suffering-in -silence-2019.pdf>.

$10 \quad$ Ibid., 6.

11 Ibid., 8. 
400.00o people, damaged 715.378 hectares of cropland and affected over 2 million people. ${ }^{12}$ It further led to 344 deaths, over 200 injuries, displacement of 16.000 households and affected over 270.000 people in Zimbabwe; while in Malawi it killed 59 people, injured 672, displaced 19.328 households and affected 732.000 people. ${ }^{13}$

Apart from Cyclone Idai and Kenneth, most disasters in Africa were scarcely reported in international media in 2019, with nine of the ten most underreported crises being in Africa. ${ }^{14}$ The effect is that they received least international focus, response and funding, with detrimental consequences to the victims.

\section{Legal and Institutional Practices in Disaster Risk Reduction, Aid Delivery and Long-Term Development in the African Region}

On the basis of the detailed analysis of the DRR legal, policy and institutional frameworks in the African region in Volume 1 of the Yearbook, this section analyses the new legal/policy/institutional developments in the Africa region in 2019 and how these are intended to enhance the capacity of the region to prevent and manage disasters in the future.

In its 32nd Heads of States Summit in February 2019, the AU adopted Decision 723 (XXXII) on Climate Change that noted its unprecedented adverse impacts on African economies and livelihoods. ${ }^{15}$ It called on AU Commission (AUC) and other Agencies to document the impact of climate change to African economies and ecosystems, and to use this evidence-base to propose policies and programmes to guide African States in climate response. ${ }^{16}$ It requested the AUC to organise an African Summit on Climate Change in 2020 prior to $\mathrm{COP}_{2} 6$ for African States and stakeholders to develop a common position on climate

12 UNDP 'Mozambique Cyclone Idai Post Disaster Needs Assessment (May 2019) 5, 14 \& 19-23, <https://www.undp.org/content/dam/undp/library/Climate\%2oand\%2oDisaster \%2oResilience/PDNA/PDNA\%2oMozambique\%2oCyclone\%2oIdai\%2o\%2o PostDisaster\%2oNeeds\%2oAssessment_Executive\%2oSummary.pdf>.

13 Federation of American Scientists, 'Cyclone Idai and Kenneth in Southeastern Africa: Humanitarian and recovery response in brief' (10 May 2019) 3, <https:/fas.org/sgp/crs/ row/R45683.pdf>.

14 CARE International (n 9).

$15 \mathrm{AU}$, 'Decision on the Katowice Climate Conference (UnfCcc COP24) and Africa's Engagements at the Global Climate Change Conference at COP25 - Assembly/AU/ Dec.723 (XXXII), paras. 14-15 <https://au.int/sites/default/files/decisions/36461-assembly _au_dec_713_-_748_xxxii_e.pdf $>$.

16 Ibid., para. 18. 
change, its impacts and responses in Africa. ${ }^{17}$ It noted Africa's challenges in accessing climate technology and financing, and called on the international community to fulfil its international climate commitments as contained in international legal/policy frameworks. ${ }^{18}$ These calls were reiterated with more urgency in AU's 33rd Heads of States Summit in February 2020 due to the climate-related hydro-meteorological hazards experienced in Africa in 2019. ${ }^{19}$ The Summit called on African States to report their adaptation efforts, needs, gaps and challenges, and further reiterated that those with the most historical responsibility for climate change ought to do more on the basis of the principle of common but differentiated responsibilities. ${ }^{20}$ Though not specifically directed at DRR, the AU Summit's climate concerns and call to action for the prevention of adverse climate impacts can go a long way in reducing loss and damage resulting from climate-related disasters in the region.

Africa's disaster vulnerability was affirmed in Africa's Common Position to the 2019 Global Platform on DRR, exemplified by the devastations of Cyclones Idai and Kenneth. ${ }^{21}$ The Common Position confirmed Africa's commitment to reduce disaster risks and strengthen disaster preparedness; but noted Africa's DRR challenges as being: increased frequency and intensity of hazards; limited understanding of nexus between hazards and climate change; inadequate institutional capacity for planning, coordination and implementation of DRR/M activities due to limited political commitment; slow progress in adopting and implementing DRR legal frameworks; limited capacity to generate requisite data for evidence-based decision-making; and inadequate domestic resource allocation to DRR. ${ }^{22}$ It sought to address these challenges by enhancing DRR institutional capacities at the national and regional levels, accelerating development of DRR legal frameworks and risk financing mechanisms at the national and regional levels, increasing understanding of DRR to ensure risk-informed development and investment, and ensuring coherence

17 Ibid., para. 25 .

18 Ibid., paras. 10-13 and 17 .

$19 \mathrm{AU}$, 'Decision on the Report of the Committee of the African Heads of State and Government on Climate Change - Assembly/AU/Dec.764 (XXXIII)' paras. 12-13 \& 20 $<$ https://au.int/sites/default/files/decisions/3818o-assembly_au_dec_749-795_xxxiii _e.pdf $>$.

$20 \quad$ Ibid., paras. 14-24.

$21 \mathrm{AU}$, 'Africa Common Position to the 2019 Global Platform on DRR held in Geneva from 13-17 May 2019' (13 May 2019) <https://www.preventionweb.net/files/67051_africacom monpositiontothe2019global.pdf $>$.

Ibid., $1-3$. 
and integration of DRR, CCA and sustainable development in regional/national policies, strategies and actions. ${ }^{23}$

Though laudable, these intentions have not been activated, with the result that risk reduction and response is still very slow or non-existent in the region. A case in point is the slow and inadequate response to Cyclone Idai by the regional institutions such as the AU and SADC, with the SADC contributing $0.05 \%$ (US\$ 500.000) of the required rehabilitation financing while the $\mathrm{AU}^{24}$ only contributed $0.035 \%$ (US $\$ 350.000) .{ }^{25}$ This limited contribution made a commentator to remark as follows: ${ }^{26}$

I wonder why they exist? During natural disasters they are always conspicuously absent, during political crises they lose their voices, despots thrive within SADC and AU (...) they should be leading every effort to help countries recover and not make a pittance of a donation!!

This is a reflection of the frustration and exasperation of many African people to the lack of progress in disaster prevention and response by the regional institutions, which ought to be addressed urgently if the increasing disaster risks are to be prevented from becoming full blown disasters.

An effort towards remedying these challenges has been the creation of the African Humanitarian Agency (AfHA) to coordinate disaster prevention and response in the region. ${ }^{27}$ AfHA's responsibility is expected to be: provision of general policy direction for an African-led humanitarian system in the region, strengthening of disaster management bodies of member countries, creating sub-regional hubs for training in DRR/M, and disaster financing mobilisation. ${ }^{28}$ Though a strong political statement for sovereignty and self-sufficiency in disaster prevention and response, the Agency's success will be dependent on availability of domestic/regional resources, development of sufficient

23 Ibid., 3-4.

$24 \mathrm{AU}$, 'The AU to contribute 350,000 USD to disaster efforts in Mozambique, Zimbabwe and Malawi and dispatch of High Level Assessment Mission' (20 March 2019) <https:// au.int/sites/default/files/pressreleases/36192-prcommunique_southern_african_disas ter_support20032019.pdf>.

25 James Hall, 'Africa's disaster response: Continent-wide coordination required' (16 April 2019) <https://www.inonafrica.com/2019/o4/16/africas-disaster-response-conti nent-wide-coordination-required/>.

$26 \quad$ Ibid.

27 Oheneba Boateng, 'Commentary: Three challenges for the AU's new Humanitarian Agency' (28 August 2019) <https://www.gppi.net/2019/08/28/three-challen ges-for-the-african-unions-new-humanitarian-agency>. 
human/logistical capacity to manage the myriad disasters and disaster risks in the African continent and the effective coordination of all the actors operating in the region.

Due to adverse disaster impacts in 2019, the AU Peace and Security Council (PSC) themed its 864th Meeting of 6 August 2019 as 'Natural and other Disasters in the Continent: Beyond the Normative Framework. ${ }^{29}$ The basis of its discussions were Articles 6(f) and 7(p) of the PSC Protocol which empowers it to undertake, facilitate and support humanitarian action and disaster management in situations of major disasters. The PSC emphasised the urgency for AU States to address risk factors contributing to natural disasters, adopt adaptation measures to build disaster and climate resilience and reinforce measures addressing climate change, environmental degradation and natural disasters. ${ }^{30}$ It called on Member States to develop effective communication mechanisms on disaster early warning systems (establishment of 24-hour command centres to closely monitor and provide timely warning on impending disasters) and improve coordination at the national, sub-regional and regional levels in planning and responding to disasters. ${ }^{31}$ It also affirmed the need for sustainable funding at the national and regional level in Africa, and called on national governments to establish special budgetary funding for disaster prevention/ response. ${ }^{32}$ To expedite regional disaster response, the PSC called for the urgent operationalization of AfHA to enable it support States in disaster preparedness and management, including through the utilisation of the African Standby Force (ASF). ${ }^{33}$ It requested the AUC to expedite finalisation of the AU Policy Guidelines on the Role of ASF in Humanitarian Action and Natural Disaster, so as to enable the ASF to actively take part in disaster prevention/ response in the continent. ${ }^{34}$ Though reactive in response to the devastation of Cyclones Idai and Kenneth, these recommendations of the Psc, if fully implemented, have the potential to enhance disaster prevention, preparedness and response in the region.

The devastation of Cyclones Idai and Kenneth also led to the formation of a new sub-regional coordination mechanism - The Disaster Risk Reduction Management Platform (DRRMP) covering seven South-East and South-West

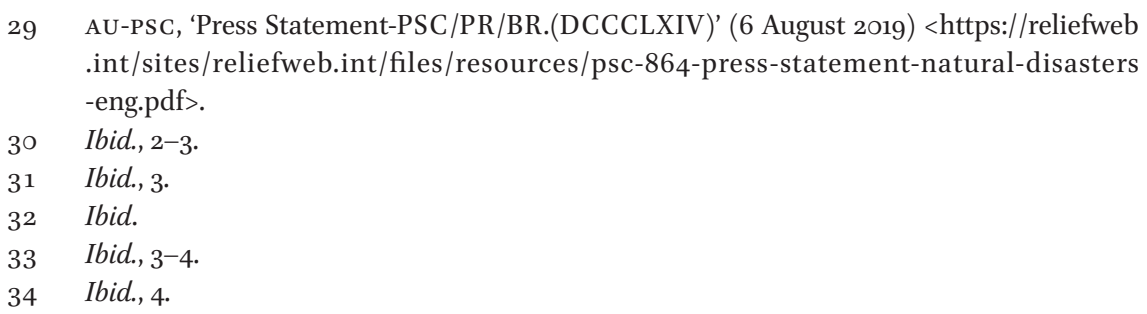


African countries. ${ }^{35}$ DRRMP's remit would be sharing disaster prevention information and knowledge, especially accurate and instantaneous early warning information on disaster risks. ${ }^{36}$ The need to form a new mechanism is an indictment of the failures of the available mechanisms under the $\mathrm{AU}$ and SADC to effectively coordinate disaster risk reduction and response in Africa.

At the national level, challenges still subsist, with budgetary funding of DRR/M very low at an average of $4 \%$ of both direct $(23.5 \%)$ and indirect $(76.5 \%)$ national budgetary allocations as per budgetary analysis of 16 African countries by UNDRR. ${ }^{37}$ The majority of this $(67 \%)$ is allocated to pre-disaster activities, with post-disaster funding mainly coming from international humanitarian assistance. ${ }^{38}$ In a world of competing interests, this national overreliance on aid for disaster prevention and response is unsustainable. African countries need to develop sustainable national risk financing and risk allocation mechanisms that adequately fund all the phases of disaster risk management cycle if they are to achieve disaster resilience in the context of increasing climaterelated hazards.

The MENA region has been classified as one of the earth's climate change hotspots, with temperature increase expected to significantly exceed the global averages, leading to the increase in frequency and intensity of droughts, sand/dust storms, heatwaves, desertification and a $10-20 \%$ reduction in annual precipitation. ${ }^{39}$ These are bound to adversely impact water availability (fresh water availability at $10 \%$ of global average), food security and human wellbeing. ${ }^{40}$ The increased temperatures alternates with erratic precipitation, with heavy rainfall over short duration of times resulting in flooding. Examples of this abound in 2019 in different countries in the region, with Saudi Arabia,

35 JICA, 'Regional cooperation to protect countries from cyclones! Seven Southeast Africa and Indian Ocean countries launch Disaster Risk Reduction Management Platform' (4 December 2019) <https://www.jica.go.jp/english/news/field/2019/20191204_02.html>.

$36 \quad$ Ibid.

37 UNDRR 'Disaster risk reduction investments in Africa' (2020) <https://www.undrr.org/ publication/disaster-risk-reduction-africa-summary-findings-16-risk-sensitive-budget -reviews $>$.

38 Ibid, 3 .

39 Manfred Lange, 'Impact of climate change on the Eastern Mediterranean and the MENA region and the water-energy nexus', (2019) Atmosphere 3 \& 5-6.

Ibid, $6-7$. 
Iraq, Iran, Jordan and Pakistan experiencing flooding. ${ }^{41}$ In April 2019, Iran faced an unprecedented two weeks of flooding when over a month's worth of rain fell in a few days (200-500 $\mathrm{mm}$ of rain) causing 141 rivers to burst their banks and around 400 landslides. ${ }^{42}$ The flooding affected 1.900 cities and 10 million people, with 365.000 temporarily displaced, led to the death of 76 people and injured 2.408 others, destroyed/damaged 179.000 houses, and also destroyed 1 million hectares of agricultural produce estimated at US\$ 350 million. ${ }^{43}$ Sudan was equally affected by flooding which occurred in 16 of its 18 States resulting in 78 casualties, affecting 364.200 people, destroying/damaging 72.846 houses. ${ }^{44}$ Other MENA countries affected by flash flooding in 2019 include Tunisia; ${ }^{45}$ Yemen (affected over 80.000 people); ${ }^{46}$ Syria (affected over 118.00o people); ${ }^{47}$ and Oman. ${ }^{48}$

\section{5 \\ Legal and Institutional Practices in Disaster Risk Reduction, Aid Delivery and Long-Term Development in the MENA Region}

The MEnA region held the 4th Arab Partnership Meeting for DRR on 9-10 December 2019 in Cairo, Egypt. ${ }^{49}$ The Meeting took stock of progress in the implementation of the Sendai Framework in the Region, especially the need to achieve target $\mathrm{E}$ by $2020 .{ }^{50}$ It discussed the need to identify and upgrade

41 JBA Risk Management, 'Deadly flash flooding hits many provinces of Iran' (2019) < https://www.jbarisk.com/flood-services/event-response/deadly-flash-flooding -hits-many-provinces-of-iran/>.

42 The Guardian, 'At least 62 people killed in Iran floods as US accused of blocking aid' (4 April 2019) <https://www.theguardian.com/world/2019/apr/o4/iran-floods-death -toll-reaches-62>.

43 UN-OCHA, 'Iran Floods - March 2019'<https://reliefweb.int/disaster/fl-2019-0ooo22-irn>.

44 UN-OCHA, 'Sudan floods -June 2019'<https://reliefweb.int/disaster/fl-2019-0ooo64-sdn>.

45 Gardaworld, 'Tunisia - Flash flooding leaves one dead in Tunis September 10' (11 September 2019) <https://www.garda.com/crisis24/news-alerts/265971/tunisia -flash-flooding-leaves-one-dead-in-tunis-september-10>.

46 Un-ocha, 'Yemen floods - June, August and October 2019' <https://reliefweb.int/ disaster/ff-2019-000054-yem>.

47 UN-OCHA, 'Syria floods - March-April 2019' <https://reliefweb.int/disaster/fl-2019 -oooo31-syr>.

48 Floodlist News, 'Oman - Deadly flash floods hit North' (24 May 2019) <http://floodlist .com/asia/oman-deadly-flash-floods-ash-sharqiyah-north-may-2o19>.

49 UNDRR, ‘4th Arab Partnership Meeting for Disaster Risk Reduction' (2019) <https://www .preventionweb.net/events/view/69059?id=69059>.

50 Arab Gulf University, 'AGU Holds 4th Arab Partnership Meeting for DRR' (23 December 2019) <https://www.agu.edu.bh/en/Media/PressReleases/Pages/Disaster -Risk-Reduction.aspx >. 
innovative solutions for the management of climate risks so as to enhance the integration of DRR, CCA and sustainable development. ${ }^{51}$ It adopted an initiative to develop an 'Atlas of Natural Hazards in the Arab Region' for purposes of increasing public awareness of disaster risks and ensuring social readiness in the mitigation of disaster effects. ${ }^{52}$ This is to be further bolstered by UNDRR-ROAS' initiative to develop an Annual Regional Assessment Report (RAR) starting in 2020.53 RAR's objective is the monitoring and continuous analysis of risk patterns (risk scenarios and underlying drivers of risk such as declining ecosystems, vulnerable livelihoods and poorly planned/managed urban development), trends and progress in DRR in the region on the basis of impartial, credible and cogent evidence. ${ }^{54}$ The generated evidence will be utilized to issue policy advise and recommendations on how to address the rapidly increasing disaster risks and exposure in the region, and to devise strategies for the integration of DRR and CCA within the broader framework of sustainable development and poverty reduction..$^{55}$

The nexus between DRR, CCA and Sustainable Development was also noted in the 2019 Arab Forum for Sustainable Development held in Beirut on 9-11 April 2019. ${ }^{56}$ The Forum noted that climate change was exacerbating developmental challenges in the region such as conflict and inequality, and addressing it was critical in reducing disaster risks and achieving sustainable development. ${ }^{57}$ The Forum recommended cross-sectorial policy integration and regional coordination so as to translate climate commitment into actions on the ground. ${ }^{58}$ It further called for the close alignment of science and policy and the development of partnerships through regional mechanisms so as to foster a culture of shared responsibility and sustained engagement. ${ }^{59}$ Finally, it called for the harmonisation of the 2030 Development Agenda with the Paris Agreement through overarching policy reforms across the region so as

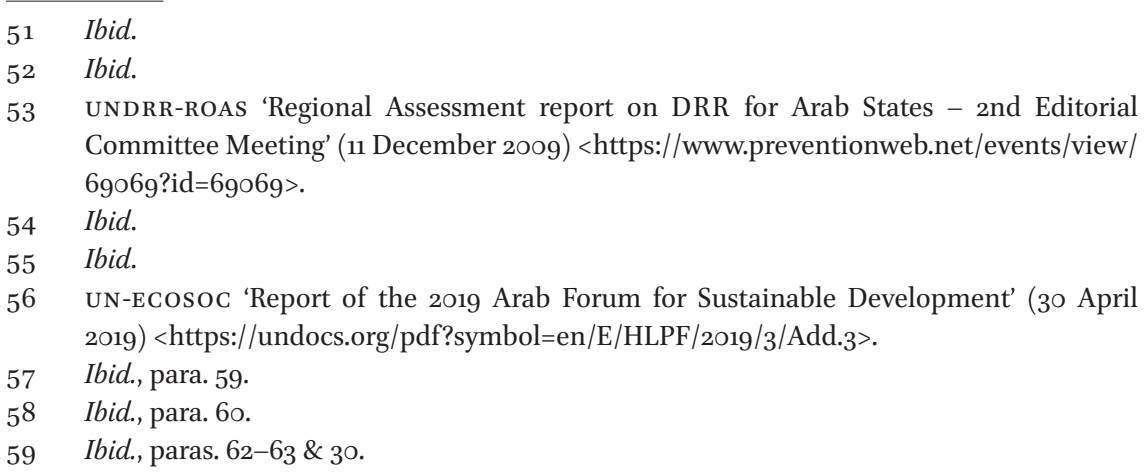


to enhance deeper integration of environmental, social and economic sectors and also enable countries of the region to tap on new sources of financing. ${ }^{60}$

The MENA challenge of rapid urbanization ( $65 \%$ of population in cities), ${ }^{61}$ highly concentrated populations ( $92 \%$ of population concentrated on $3 \%$ of land) and poorly planned/managed urban development was the focus of MENA Region Urban Resilience Conference supported by the World Bank held on 2-4 April 2019 in Beirut, Lebanon. ${ }^{62}$ The Conference noted that amplified exposure of the urban population to unprecedented natural and social hazards had affected over 40 million people and cost MENA economies nearly US\$2O billion. ${ }^{63}$ In response, the Conference called for integrated risk-informed spatial/territorial planning, "whole-of-society" participatory approaches to decision-making and urban resilience investment (risk-informed budgeting and public/private partnerships to diversify funding sources) so as to promote sustainable development and poverty reduction. ${ }^{64}$ In its 'Way Forward', the Conference recommended the development and operationalisation of community-based disaster management plans, governmental support for urban regeneration safety assurance plans, and policy reforms to enhance public-private partnership for long-term innovative financing solutions for urban resilience. ${ }^{65}$

Regional actors also adopted the Riyadh Declaration on Recognising the Role of ICT for Disaster Risk Reduction and Management in the Arab Region in a regional Multi-Stakeholder Workshop organized by the Arab Red Crescent/ Cross Organization (ARCO) and International Telecommunications Union (ITU) in Riyadh on $26-28$ November $2019 .{ }^{66}$ The Declaration calls on Arab States and other stakeholders to cooperate and unify their national strategies to promote the effective use of ICт as a cross-cutting tool for development and disaster risk reduction (multi-hazard early warning systems, disaster risk information exchanges and Common Alert Protocols) in the region in accordance

\footnotetext{
6o Ibid., para. 17 .

61 Ahmed El-Kholei, 'Are Arab cities prepared to face disaster risks? Challenges and opportunities', (2019) 58 Alexandria Engineering Journal, 479-486.

62 World Bank 'MENA Regional Urban Resilience Conference Proceedings Report' (2019) $<$ http://pubdocs.worldbank.org/en/999321574188467376/MENA-Regional-Urban -Resilience-Conference-EN.pdf>.

63 Ibid., 6-7.

64 Ibid., 11 and $19-20$.

65 Ibid., 21.

66 ARCo, 'Riyadh Declaration' (28 November 2019) < https://www.itu.int/en/ITU-D/ Regional-Presence/ArabStates/Documents/events/2019/DRR/RIYADH\%20\%20Dec laration\%2oon\%2oRole\%2oof\%2oTelecommunications\%2oand\%2oICTs\%2ofor\%20 DRR_28\%20Nov\%2O2019.pdf>.
} 
with the principle of common responsibility of Arab countries. ${ }^{67}$ It proposes that the entrenchment of ICT in DRR be achieved at the national level through the adoption of national legislation, regulatory frameworks and guidelines that support the use of ICT in all stages of the disaster risk management cycle, especially early warning and monitoring systems in accordance with the Tampere Convention on the Provision of Telecommunication Resources for Disaster Mitigation and Relief Operations. ${ }^{6}$

On the challenge of national DRR financing, some MENA countries are taking action to cushion important sectors of their economy from adverse impacts of disasters through increased insurance coverage. Tunisia, for example, adopted a Decree on the establishment of an Agricultural Damage Compensation Fund designed to compensate un-insured agricultural farmers for losses resulting from natural disasters such as floods, storms, drought and frost/snow. ${ }^{69}$ The Fund is financed by annual State subsidy of US\$12.2 million, annual $2.5 \%$ of insured value contribution by farmers who are members of the fund, and a $1 \%$ solidarity tax on agricultural export products. ${ }^{70}$ Claims are to be compensated at $60 \%$ of the product value from the Fund if the resulting disaster loss is due to climate change, is of exceptional intensity, is inevitable and irrepressible, and triggers heavy material losses. ${ }^{71}$ The essence of the Fund is to cushion the agricultural sector from the increasingly recurrent natural hazard due to the importance of agriculture to Tunisia's economy. ${ }^{72}$

On 21 March 2019, Morocco adopted a Draft Decree that made it compulsory for all Moroccans to take out natural and human-made disaster insurance. ${ }^{73}$ The Decree established a Solidarity Fund against Catastrophic Events (FSEC) to cushion victims of natural disasters who were unable to take out the compulsory disaster insurance. ${ }^{74}$ The FSEC is funded through a Solidarity Tax

\footnotetext{
$67 \quad$ Ibid.

68 Ibid.

69 Atlas Magazine, 'Insurance of agricultural risks in Tunisia' (30 April 2019) <https://www .atlas-mag.net/en/article/insurance-of-agricultural-risks-in-tunisia $>$.

$70 \quad$ Ibid.

71 Ibid.

72 Atlas Magazine, 'The forthcoming establishment of a fund to prevent natural catastrophes in Tunisia' (28 March 2019) <https://www.atlas-mag.net/en/article/ creation-prochaine-d-un-fond-de-lutte-contre-les-catastrophes-naturelles-en-tunisie>.

73 Asharq Al-Aswat, 'Morocco to begin compulsory insurance for natural disasters early 2020' (24 September 2019) <https://aawsat.com/english/home/article/1916871/ morocco-begin-compulsory-insurance-natural-disasters-early-2020 >.

74 Atlas Magazine, 'Natural catastrophes cover: Adoption of the Draft Decree' (26 March 2019) <https://www.atlas-mag.net/en/article/natural-catastrophes-cover -adoption-of-the-draft-decree>.
} 
Against Disastrous Events, which is a $1 \%$ tax paid on insurance premiums and other contributions made under insurance contracts, with the exception of life insurance contracts. ${ }^{75}$ Morocco's efforts have been bolstered by World Bank's US\$ 275 million Disaster Risk Management Development Policy Loan to enhance immediate governmental access to liquidity in the event of natural disasters over a 15-year period. ${ }^{76}$ The Loan Facility will support reforms designed to strengthen the financial, governance and operational frameworks of the FSEC as well as develop a registry of beneficiaries to ensure timely and targeted compensation to victims of disasters. ${ }^{77}$ Through the Facility, Morocco would be able to upgrade its institutional framework for disaster risk management by strengthening its National Civil Protection Systems as well as creating a National Flood Risk Management Information System. ${ }^{78}$

75 Morocco World News, 'Moroccan Government to approve natural disaster tax' (10 September 2019) <https://www.moroccoworldnews.com/2019/og/282335/moroccan -government-natural-disaster-tax/>.

76 World Bank, 'Upgrading Morocco's Risk Management Strategy' (11 December 2019) <https://www.worldbank.org/en/news/press-release/2019/12/11/upgrading-moroc cos-disaster-risk-management-strategy >

$77 \quad$ Ibid.

78 Ibid. 